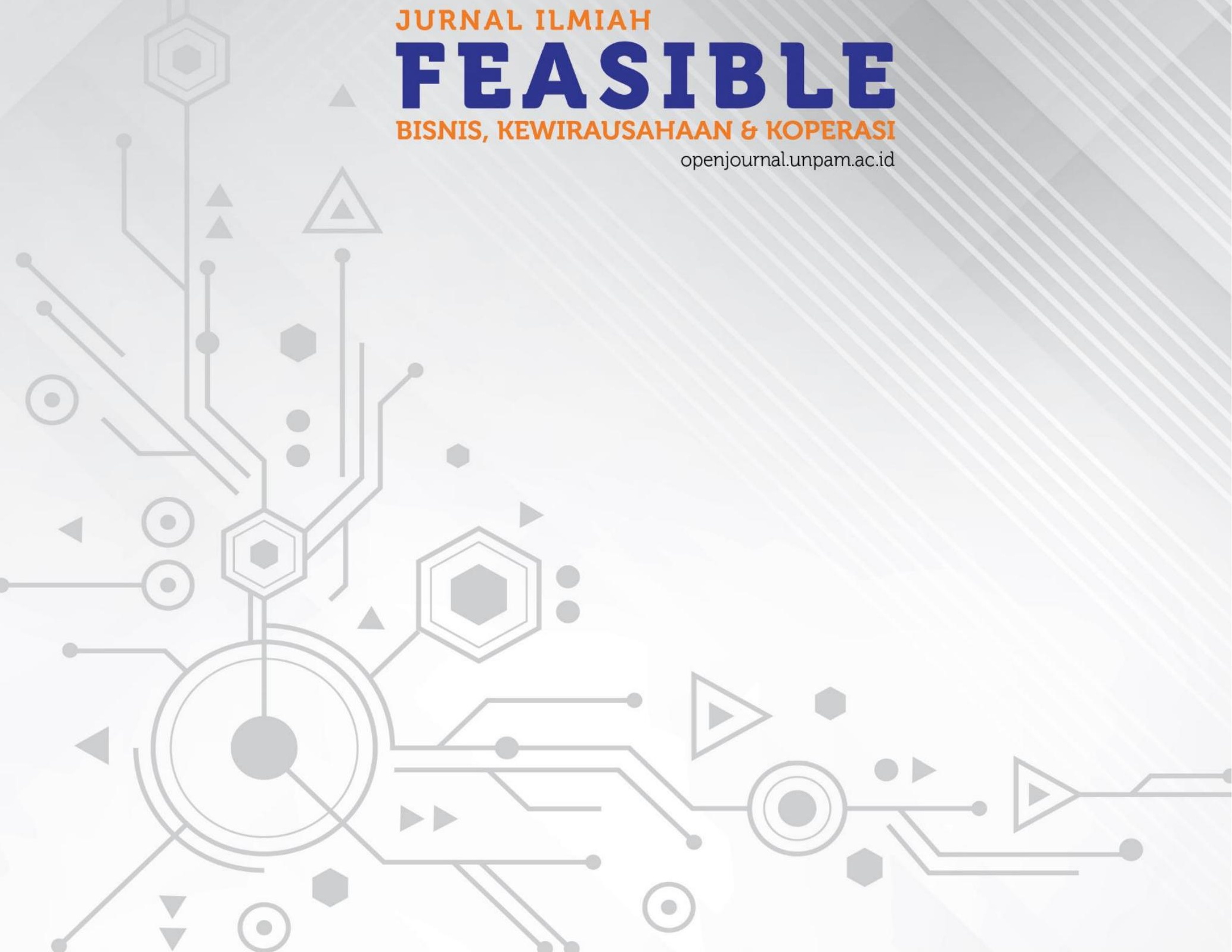





\title{
PENGARUH RETURN ON EQUITY DAN EARNING PER SHARE TERHADAP HARGA SAHAM PADA PT BANK NEGARA INDONESIA (PERSERO) TbK PERIODE 2009-2017
}

\author{
Rita Satria \\ Fakultas Ekonomi, Universitas Pamulang \\ dosen01679@unpam.ac.id
}

\begin{abstract}
Abstrak
Tujuan dari penelitian ini adalah untuk mengetahui pengaruh Return on Equitydan Earning Per Share terhadap Harga Saham pada PT Bank Negara Indonesia Tbk secara parsial dan simultan. Populasi dari penelitian ini adalah laporan keuangan PT Bank Negara Indonesia Tbk dan sampel penelitian adalah laporan keuangan berupa neraca dan laporan laba rugi periode 2009-2017. Metode analisis yang digunakan adalah analisis statistik deskriptif, uji asumsi klasik (uji normalitas, uji multikoleniaritas, uji autokorelasi, uji heteroskedastisitas), uji hipotesis (uji parsial dan uji simultan), analisis koeefisien determinasi, analisis korelasi, dan analisis regresi linear berganda. Hasil analisis regresi linear berganda adalah $Y=-$ $533,922+3,615 X_{1}+10,892 X_{2}$. Hasil uji parsial diperoleh bahwa Return on Equity tidak pengaruh signifikan terhadap terhadap Harga Saham. Sedangkan Earning Per Share berpengaruh positif dan signifikan terhadap Harga Saham. Uji F memperoleh hasil $F_{\text {hitung }}$

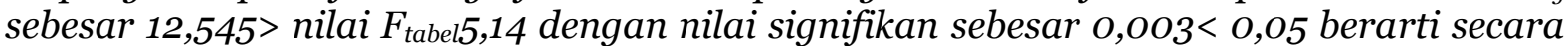
simultan Return On Equity dan Earning Per Share memiliki pengaruh positif dan signifikan terhadap Harga saham dengan kontribusi sebesar 80,7\% dan sisanya 19,3\% dipengaruhi oleh faktor lain.
\end{abstract}

Kata Kunci: Return on Equity (ROE); Earning Per Share (EPS); Harga Saham

\begin{abstract}
The purpose of this study was to determine the effect of Return on Equity and Earning Per Share on Share Prices at PT Bank Negara Indonesia Tbk partially and simultaneously. The population of this study is the financial statements of PT Bank Negara Indonesia Tbk and the research sample is financial statements in the form of balance sheets and income statements for the period 2009-2017. The analytical method used is descriptive statistical analysis, classical assumption test (normality test, multicollinearity test, autocorrelation test, heteroscedasticity test), hypothesis testing (partial test and simultaneous test), determination coefficient analysis, correlation analysis, and multiple linear regression analysis. The result of multiple linear regression analysis is $Y=-533,922+3,615 X 1+10,892$ X2. The partial test results show that Return on Equity has no significant effect on stock prices. Meanwhile, Earning Per Share has a positive and significant effect on stock prices. $F$ test results Fcount of 12.545> Ftable value 5.14 with a significant value of $0.003<0.05$ means that simultaneously Return On Equity and Earning Per Share have a positive and significant effect on stock prices with a contribution of $80.7 \%$ and the remaining $19,3 \%$ is influenced by other factors.
\end{abstract}

Keywords: Return on Equity (ROE); Earning Per Share (EPS); Stock Price 
JURNAL ILMIAH FEASIBLE: Bisnis, Kewirausahaan \& Koperasi, Vol.2.No.2 Agustus 2020: 204 - 216

\section{PENDAHULUAN}

\section{Latar Belakang}

Pasar modal merupakan alternatif penghimpunan dana selain sistem perbankan. Penghimpunan dana melalui pasar modal dapat berupa kepemilikan saham oleh masyarakat Pergerakan saham pada umumnya dipengaruhi beberapa faktor menurut pendapat Natarsyah dalam Menurut Kasmir (2012:207) dalam Nurfadilah (2011) bahwa, faktor-faktor yang mempengaruhi tingkat pergerakan saham yaitu faktor eksternal dan internal. Faktor eksternal atau tekhnikal yaitu untuk mempelajari tentang perilaku pasar yang diterjemahkan kedalam grafik riwayat harga dengan tujuan untuk memprediksi harga di masa yang akan datang. Sedangkan faktor internal atau faktor fundamental adalah studi tentang ekonomi, industri dan kondisi perusahaan untuk memperhitungkan nilai dari saham perusahaan.

Penilaian saham secara akurat bisa meminimalkan resiko sekaligus membantu investor mendapatkan keuntungan wajar, mengingat investasi saham di pasar modal merupakan jenis investasi yang beresiko tinggi meskipun menjanjikan keuntungan relatif besar. Investasi di pasar modal. .

Harga saham merupakan nilai sekarang dari penghasilan yang akan diterima oleh pemodal dimasa yang akan datang. Harga saham menunjukkan prestasi perusahaan yang bergerak searah dengan kinerja perusahaan. Perusahaan yang memiliki prestasi yang baik dapat meningkatkan kinerja perusahaannya yang tercermin dari laporan keuangan perusahaan, sehingga investor akan tertarik untuk berinvestasi pada perusahaan tersebut. Peningkatan permintaan investor terhadap perusahaan tersebut akan menyebabkan harga saham perusahaan yang bersangkutan cenderung meningkat pula. Harga saham merupakan faktor yang sangat penting dan harus diperhatikan oleh investor dalam melakukan investasi karena harga saham menunjukkan prestasi emiten. Harga saham di pasar modal terdiri atas tiga kategori, yaitu harga tertinggi (high price), harga terendah (low price) dan harga penutupan (close price). Harga tertinggi atau terendah merupakan harga yang paling tinggi atau paling rendah yang terjadi pada satu hari bursa. Harga penutupan merupakan harga yang terjadi terakhir pada saat akhir jam bursa.

Laporan keuangan perusahaan dapat menjadi acuan bagi investor dalam pengambilan keputusan investasi, seperti menjual, membeli, atau menanam saham. Harga saham setiap waktu dapat berubahubah tergantung pada besarnya penawaran dan permintaan investor akan saham tersebut. Faktor-faktor yang dapat memengaruhi naik turunnya harga saham suatu perusahaan adalah faktor internal dan faktor eksternal perusahaan tersebut. Faktor internal perusahaan yang digunakan berupa rasio-rasio keuangan seperti rasio profitabilitas yang diproksikan dengan Return on Equity (ROE) dan rasio 
pasar yang diproksikan dengan Earning Per Share (EPS).

ROE adalah rasio yang digunakan untuk mengukur tingkat penghasilan bersih yang diperoleh perusahaan atas modal yang diinvestasikannya. Semakin besar rasio ROE menggambarkan semakin baik keadaan perusahaan, sehingga akan meningkatkan kepercayaan investor untuk menanamkan modalnya. Nurfadilah (2011) menyatakan bahwa ROE mempunyai pengaruh signifikan terhadap harga saham. Berbeda dengan penelitian Utami yang menyatakan ROE tidak mempunyai pengaruh terhadap harga saham.

Rasio ini membandingkan antara laba setelah pajak dengan modal sendiri. Earning after tax Return on Equity (ROE) = Total equity. Menurut Silalahi (2012) rasio ini banyak diamati oleh para pemegang saham serta para investor di pasar modal yang ingin membeli saham suatu perusahaan. Dengan demikian ROE merupakan indikator yang amat penting bagi pemegang saham dan calon investor untuk mengukur kemampuan suatu perusahaan dalam memperoleh laba bersih yang dikaitkan dengan pembayaran dividen dan kenaikan harga saham.

Semakin tinggi ROE berarti semakin baik kinerja perusahaan dalam mengelola modalnya untuk menghasilkan keutungan bagi pemegang saham (Hutami, 2012) Silalahi (2012) membuktikan bahwa terdapat pengaruh negative ROE terhadap harga saham pada perusahaan perbankan. Sedangkan Tiningrum (2011) membukti- kan bahwa tidak terdapat pengaruh signifikan ROE terhadap harga saham pada perusahaan manufaktur. Ratih, Apriatni dan Saryadi (2013) pada penelitiannya terhadap perusahaan pertambangan membuktikan hal yang berbeda yaitu bahwa ROE berpengaruh positif signifikan terhadap harga saham. Hutami (2012), Sihasale (2001) serta Uli dan Sularto (2009) berpendapat sama bahwa ROE pada perusahaan manufaktur berpengaruh positif Dengan memperhatikan kecendrungan dari hasil penelitian sebelumnya yang dilakukan pada beberapa sektor perusahaan, maka dapat ditarik kesimpulan sementara bahwa secara umum ROE berpengaruh positif signifikan terhadap harga saham.

EPS adalah rasio pasar yang digunakan untuk mengukur seberapa besar pengakuan pasar akan suatu perusahaan dengan membandingkan antara laba bersih dengan jumlah lembar saham yang beredar di pasaran. EPS yang meningkat menandakan bahwa perusahaan berhasil meningkatkan kemakmuran investor dengan berupa pembagian dividen. Hal ini dapat meningkatkan permintaan investor akan saham yang nantinya akan menyebabkan semakin meningkat pula harga saham perusahaan tersebut. Penelitian yang dilakukan oleh Shubiri (2010), menemukan bahwa secara parsial EPS memiliki pengaruh yang positif signifikan terhadap harga saham pada Bank Komersial di Yordania. Berbeda dengan penelitan yang dilakukan oleh 
Iqbal Khan (2010), menemukan bahwa EPS berpengaruh negatif dan tidak signifikan terhadap harga saham pada Industri Kimia dan Farmasi.

Menurut Kasmir (2011:207), Earning Per Share (EPS) adalah rasio untuk mengukur keberhasilan manajemen dalam mencapai keuntungan bagi pemegang saham. Rasio yang rendah berarti manajemen belum berhasil memuaskan pemegang saham, sebaliknya dengan rasio yang tinggi, maka ksejahteraan pemegang saham meningkat. Dengan kata lain tingkat pengembalian yang tinggi.

Harga saham merupakan harga yang terjadi di pasar bursa pada saat tertentu yang ditentukan oleh pelaku pasar dan ditentukan oleh permintaan dan penawaran saham yang bersangkutan di pasar modal. Harga suatu saham akan cenderung turun jika terjadi kelebihan penawaran. Pergerakan saham pada umumnya dipengaruhi beberapa faktor menurut pendapat Natarsyah dalam Egie Selamet Apriani (2013) bahwa, faktorfaktor yang mempengaruhi tingkat pergerakan saham yaitu faktor eksternal dan internal. Faktor eksternal atau tekhnikal yaitu untuk mempelajari tentang perilaku pasar yang diterjemahkan kedalam grafik riwayat harga dengan tujuan untuk memprediksi harga di masa yang akan datang. Sedangkan faktor internal atau faktor fundamental adalah studi tentang ekonomi, industri dan kondisi perusahaan untuk memperhitungkan nilai dari saham perusahaan. Faktor fundamental menitikberatkan pada kata kunci dalam laporan keuangan untuk memperhitungkan apakah harga saham sudah diapresiasi secara akurat (Dewi Karlina, 2016)

Rasio ROE sebagai faktor yang mempengaruhi harga saham, karena ROE merupakan rasio yang mewakili pengambilan atas seluruh aktivitas perusahaan. Sementara EPS dipilih karena EPS menunjukkan berapa rupiah laba yang diterima investor atas setiap lembar saham. Ketiga variabel tersebut diduga menjadi pertimbangan para investor dalam membeli saham dan memiliki keuntungan dapat memengaruhi harga saham. Berikut nilai ROE, dan EPS terhadap Harga Saham PT Bank Negara indonesia Tbk. Harga saham setiap waktu dapat berubah-ubah tergantung pada besarnya penawaran dan permintaan investor akan saham tersebut. Faktorfaktor yang dapat memengaruhi naik turunnya harga saham suatu perusahaan adalah faktor internal dan faktor eksternal perusahaan tersebut.

Penelitian ini menggunakan faktor internal perusahaan yang tercermin dalam laporan keuangan perusahaan. Faktor internal perusahaan yang digunakan berupa rasio-rasio keuangan seperti rasio profitabilitas yang diproksikan dengan Return on Asset (ROA), Return on Equity (ROE) dan rasio pasar yang diproksikan dengan Earning Per Share (EPS). Penelitian ini bertujuan untuk mengetahui 
"Pengaruh ROE, dan EPS Terhadap

Harga Saham PT Bank Negara Indonesia (Persero) Tbk Periode 2009-2017"

\section{Perumusan Masalah}

Rumusan masalah yang dapat disusun meliputi:

1. Bagaimana pengaruh ROE terhadap Harga Saham PT Bank Negara Indonesia Tbk Periode 2009-2017?

2. Bagaimana pengaruh EPS terhadap Harga Saham PT Bank Negara Indonesia Tbk Periode 2009-2017?

3. Bagaimana pengaruh, ROE, dan EPS secara bersama-sama terhadap Harga Saham PT Bank Negara Indonesia Tbk Periode 2009-2017?

\section{Tujuan Penelitian}

Tujuan yang diinginkan dalam penelitian ini antara lain:

1. Untuk mengetahui pengaruh pengaruh ROE terhadap Harga Saham PT Bank Negara Indonesia Tbk Periode 20092017.

2. Untuk mengetahui pengaruh pengaruh EPS terhadap Harga Saham PT Bank Negara Indonesia Tbk Periode 200920017.

3. Untuk mengetahui pengaruh ROE dan EPS secara bersama-sama terhadap Harga Saham PT Bank Negara Indonesia Tbk 2009-2017.

\section{Hipotesis}

Hipotesis yang dapat disusun:
H1: Diduga terdapat pengaruh ROE terhadap Harga Saham PT Bank Negara Indonesia Tbk.

H2: Diduga terdapat pengaruh EPS terhadap Harga Saham PT Bank Negara Indonesia Tbk.

H3: Diduga terdapat pengaruh, ROE , dan EPS secara bersama-sama terhadap Harga SahamPT Bank Negara Indonesia Tbk.

\section{Kajian Literatur}

\section{Manajemen}

1. Pengertian Manajemen

Pengertian manajemen secara umum merupakan suatu kegiatan untuk mengatur, memimpin, mengelola, mengembangkan dan mengendalikan usaha yang dilakukan oleh anggota organisasi serta pemanfaatan sumber daya yang tersedia untuk mencapai tujuan organisasi yang telah dimanfaatkan sebelumnya. Manajemen juga dapat didefinisikan sebagai sebuah seni. Menurut G.R. Terry (2010:16) menjelaskan bahwa "Manajemen merupakan suatu proses khas yang terdiri atas tindakan-tindakan perencanaan, pengorganisasian, penggerakan, dan pengendalian untuk menentukan serta mencapai tujuan melalui pemanfaatan sumber daya manusia dan sumber daya lainnya”.

2. Fungsi Manajemen

Fungsi Manajemen adalah berbagai jenis tugas atau kegiatan manajemen yang mempunyai peranan 
JURNAL ILMIAH FEASIBLE: Bisnis, Kewirausahaan \& Koperasi, Vol.2.No.2 Agustus 2020: 204 - 216

khas dan bersifat saling menunjang untuk mencapai tujuan yang ditetapkan sebelumnya.

\section{Manajemen Keuangan}

1. Pengertian Keuangan

Keuangan adalah istilah yang tidak asing di telinga. Istilah ini terutama digunakan di dalam ilmu ekonomi, secara khusus akuntansi. Kata keuangan juga bisa digunakan di dalam interaksi keseharian. Dalam penggunaan istilah dalam kehidupan sehari-hari, biasanya keuangan dipahami sebagai keadaan uang atau kondisi ekonomi seseorang. Menurut pendapat Le Coutre dan Hasenack dalam Riyanto (2010:3) bahwa “ Keuangan adalah pembelanjaan yang meliputi keseluruhan usaha untuk mempersiapkan dan mengatur penarikan dan penggunaan dana dimana disini termasuk juga perencanaan beserta pelaksanaannya”.

2. Pengertian Manajemen Keuangan

Manajemen Keuangan adalah segala kegiatan atau aktivitas perusahaan yang berhubungan dengan bagaimana cara memperoleh pendanaan modal kerja, menggunakan atau mengalokasikan dana, dan mengelola aset yang dimiliki untuk mencapai tujuan utama perusahaan.

3. Fungsi Manajemen Keuangan
Fungsi dari manajemen keuangan diantaranya adalah Keputusan Investasi, Fungsi Pendanaan dan Keputusan Pengelolaan Aset. Definisi manajemen keuangan menurut Grestenberg Hamper sama dengan James Van Horne yaitu bagaimana sebuah perusahaan bias memperoleh, menggunakan dananya hingga cara agar profit dari bisnis tersebut bias terdistribusikan dengan baik.

\section{Laporan Keuangan}

Laporan keuangan oleh perusahaan harus dibuat dan disusun sesuai dengan aturan atau standar yang berlaku. Hal ini perlu dilakukan agar laporan keuangan mudah dibaca dan dimengerti. Laporan keuangan yang disajikan perusahaan sangat penting bagi manajemen dan pemilik perusahaan. Disamping itu banyak pihak yang memerlukan dan berkepentingan terhadap laporan keuangan yang dibuat perusahaan, seperti pemerintah, kreditor, investor, maupun para supplier.

\section{Return On Equity (ROE)}

Kemampuan perusahaan menghasilkan laba dari modal sendiri yang digunakan. Dengan mengetahui rasio ini, akan dapat diketahui apakah perusahaan dalam memanfaatkan aktiva atas modal sendiri dalam kegiatan operasionalnya perusahaan. Rasio ini juga memberikan ukuran yang lebih baik atas profitabilitas perusahaan karena menunjukan efektifitasnya manajemen dalam meng- 
gunakan modal untuk memperoleh pendapatan.

\section{Earning per Share (EPS)}

Earning per Share (EPS) merupakan rasio yang menunjukkan besarnya laba bersih perusahaan yang siap dibagikan bagi semua pemegang saham perusahaan. Investor yang membeli saham berarti investor membeli prospek perusahaan, yang tercermin pada laba per saham, jika laba persaham lebih tinggi, maka prospek perusahaan lebih baik, sementara jika laba per saham lebih rendah berarti kurang baik.

\section{Harga Saham}

Menurut Hendro (2014, hal. 357) "saham merupakan penyertaan modal seseorang atau pihak (badan usaha) dalam suatu perusahaan atau perseroan. Pemegang saham dapat memperoleh keuntungan saham berupa 1) dividen yaitu pembagian keuntungan yang dibagikan perusahaan; 2) Capital gain yaitu selisih antara harga beli dan harga jual, terbentuk dari aktivitas perdagangan saham di pasar sekunder”.

\section{METODE}

\section{Ruang Lingkup Penelitian}

\section{Lokasi Penelitian}

Perusahaan yang menjadi objek penelitian ini adalah PT Bank Negara Indonesia Tbk (Persero) Beralamat di jl jendral Sudirman Kav 1 Jakarta 10220. Proses ini mencakup keseluruhan kerja mulai dari penetapan judul sampai pada proses pelaporan hasil penelitian.

\section{Waktu Penelitian}

Waktu penelitian dilakukan selama 6 bulan dari bulan Januari 2019 sampai dengan Juli 2019. Penelitian dilakukan secara bertahap disesuaikan dengan tingkat kebutuhan penulis, diawali persiapan penulisan proposal judul penelitian, seminar proposal, penyempurnaan materi proposal, pembuatan instrumen penelitian, pengumpulan data primer dan sekunder, pengolahan data, sampai kepada penyusunan akhir.

\section{Objek Penelitian}

Penelitian ini termasuk dalam ruang lingkup penelitian manajemen keuangan, secara khusus membahas mengenai pengaruh ROE dan EPS terhadap Harga Saham, PT Bank Negara Indonesia (Persero) Tbk periode 2011-2017.

\section{Populasi dan Sampel}

Penelitian ini menggunakan polpulasi data laporan keuangan PT Bank Negara Indonesia (Persero) Tbk. Sedangkan sampel dalam penelitian ini adalah data laporan keuangan berupa ( neraca dan laporan laba rugi PT Bank Negara indonesia (Persero) Tbk, periode tahun 2009-2017)

\section{Metode Pengumpulan Data}

Metode pengumpulan data yang digunakan dalam penelitian ini adalah data sekunder. Data sekunder merupakan data 
primer yang telah diolah lebih lanjut dan disajikan baik oleh pihak pengumpul data primer, atau oleh pihak lain.

\section{Metode Analisis Data}

\section{Uji Statistik Deskriptif}

Statistik deskriptif adalah statistik yang digunakan untuk mengalisis data dengan cara menjelaskan gambaran data yang telah terkumpul sebagaimana adanya atau hasilnya tanpa bermaksud untuk membuat kesimpulan yang berlaku secara umum.

\section{Pengujian Asumsi Klasik}

Pengujian asumsi klasik diperlukan sebelum dilakukan pengujian hipotesis.
a. Uji Normalitas
b. Uji Heteroskedastisitas
c. Uji Autokorelasi
d. Uji Multikolinearitas

\section{Analisis Regresi Linear Berganda}

Metode regresi linear berganda adalah cara meramalkan nilai Y, jika ada lebih dari satu variabel bebas $\mathrm{X}$ yang mempengaruhi $\mathrm{Y}$, dimasukkan dalam persamaan regresi $\mathrm{Y}=\mathrm{a}+\mathrm{b}_{1} \mathrm{X}_{1}+\mathrm{b}_{2} \mathrm{X}_{2}$ Dimana :

$\mathrm{Y}=$ Variabel terikat (Harga Saham)

$\mathrm{X}_{1}=$ Variabel bebas ke satu (ROA)

$\mathrm{X}_{2}=$ Variabel bebas ke dua (ROE)

\section{HASIL dan PEMBAHASAN}

\section{Hasil}

\section{Uji Normalitas}

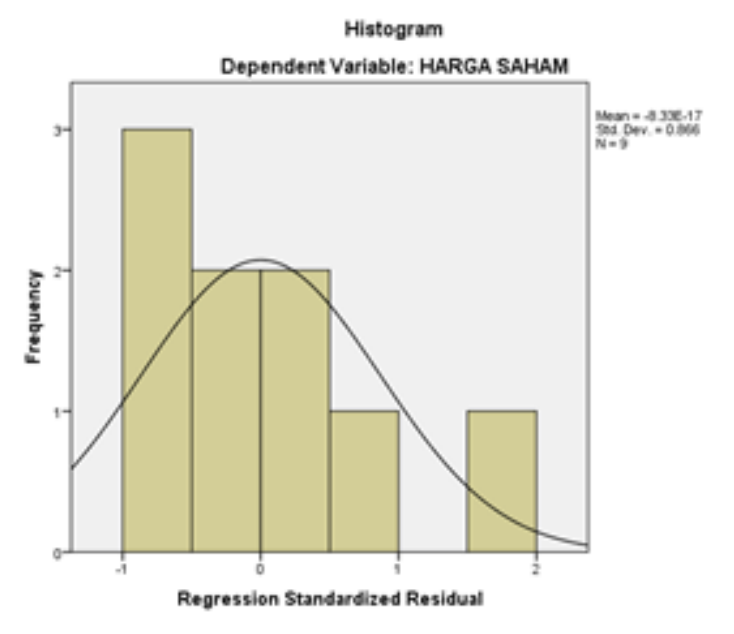

Gambar 1.1. . Uji Normalitas Histogram

Berdasarkan gambar histogram di atas menunjukkan bahwa data terdistribusi secara normal karena bentuk kurva memiliki kemiringan yang cenderung imbang dan kurva mendekati pola distribusi normal.

\section{Normal Probability Plot}

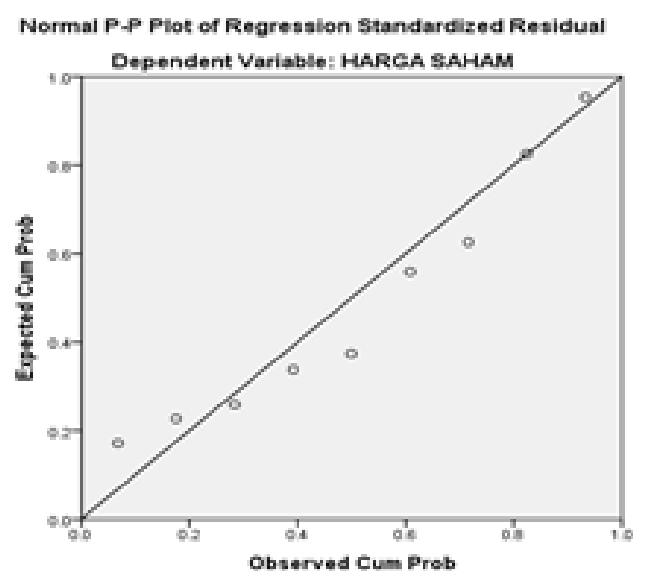

\section{Gambar 1.2. Gambar normat P-P Plot}

Berdasarkan gambar P-P Plot. Mod di atas dapat dilihat bahwa grafik el regresi dikatakan memenuhi asumsi normalitas apabila pada probability plot menunjukkan pola grafik yang normal, yaitu sebaran titik-titiknya menyebar disekitar garis diagonal dan mengikuti garis diagonal. 


\section{Uji Heteroskedastisitas}

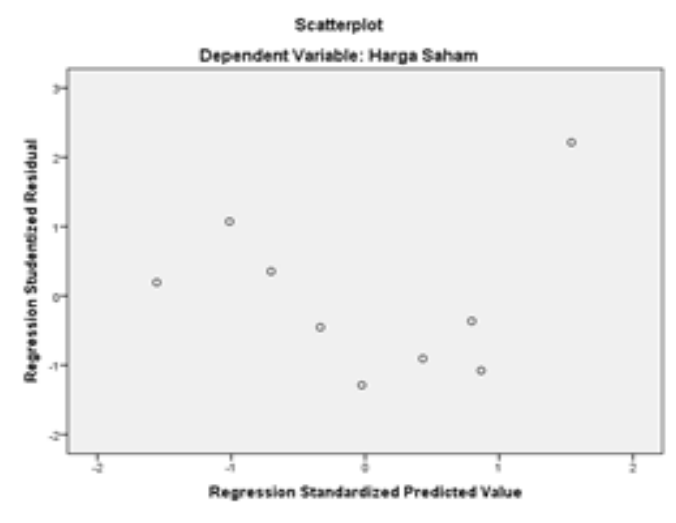

Gambar 1.3. Grafik sebaran Residual

Dari output grafik di atas, karena titik-titik tidak membentuk pola yang jelas dan menyebar di atas dan di bawah angka o pada sumbu Y berarti tidak terjadi masalah heteroskedastisitas dalam model regresinya.

\section{Uji Autokorelasi}

\section{Uji Durbin Watson}

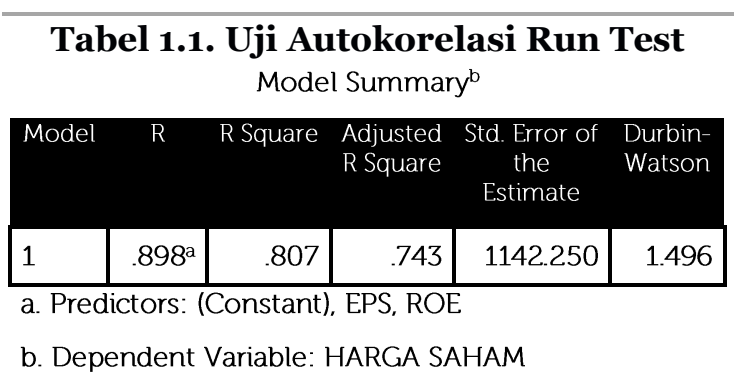

Hasil uji run test diperoleh nilai Asymp, Sig. (2-tailed) 1,00o karena nilainya lebih besar dari 0,05 maka tidak terdapat gejala autokorelasi pada model.

\section{Uji Multikolinearitas}

Tabel 1.2. Tabel Uji Multikolinieritas

\begin{tabular}{||c|r|r|}
\hline \multicolumn{1}{|c|}{ Model } & \multicolumn{2}{|c|}{ Collinearity Statistics } \\
& Tolerance & \multicolumn{1}{c|}{ VIF } \\
\hline (Constant) & & \\
\hline ROE & .982 & 1.018 \\
\hline EPS & .982 & 1.018 \\
\hline
\end{tabular}

Dari tabel di atas diperoleh nilai tolerance ROE dan EPS semuanya lebih kecil dari 1,0 sehingga tidak ada masalah multikolinearitas.

\section{Uji Hipotesis}

\section{Uji Signifikansi (Uji Parsial )}

\begin{tabular}{|r|r|r|r|r|r|}
\hline \multicolumn{7}{|c|}{ Tabel 1.3. Output Uji t } \\
\hline Model & \multicolumn{2}{|c|}{$\begin{array}{c}\text { Unstandardized } \\
\text { Coefficients }\end{array}$} & $\begin{array}{c}\text { Standar } \\
\text { dized } \\
\text { Coeffi } \\
\text { cients }\end{array}$ & $\mathbf{T}$ & Sig. \\
& \multicolumn{1}{|c|}{ B } & $\begin{array}{c}\text { Std. } \\
\text { Error }\end{array}$ & Beta & & \\
\hline $\begin{array}{r}\text { (Cons- } \\
\text { tant) }\end{array}$ & -533.992 & 1314.68 & & -406 &.-699 \\
$\mathbf{1}$ ROE & 3.615 & 6.107 & .107 & .592 & .576 \\
EPS & 10.892 & 2.246 & .878 & 4.849 & .003 \\
\hline
\end{tabular}

Berdasarkan hasil pengujian uji t di atas:

1) Hasil pengujian secara parsial (uji t) antara $R O E$ terhadap Harga Saham diperoleh $t_{\text {hitung }}=0,592>t_{\text {tabel }}(2,365)$ dengan nilai signifikansi 0,576 artinya $\mathrm{Ho}_{1}$ diterima dan $\mathrm{Ha}_{1}$ ditolak sehingga disimpulkan secara parsial $R O E$ tidak berpengaruh terhadap harga saham.

2) Hasil pengujian secara parsial (uji t) antara EPS terhadap Harga Saham diperoleh $t_{\text {hitung }}=4,849>t_{\text {tabel }}(2,365)$ dengan nilai signifikansi 0,003 artinya $\mathrm{Ho}_{1}$ ditolak dan $\mathrm{Ha}_{1}$ diterima sehingga disimpulkan secara parsial EPS berpengaruh signifikan terhadap harga saham.

\section{Uji Signifikansi (Uji Simultan)}

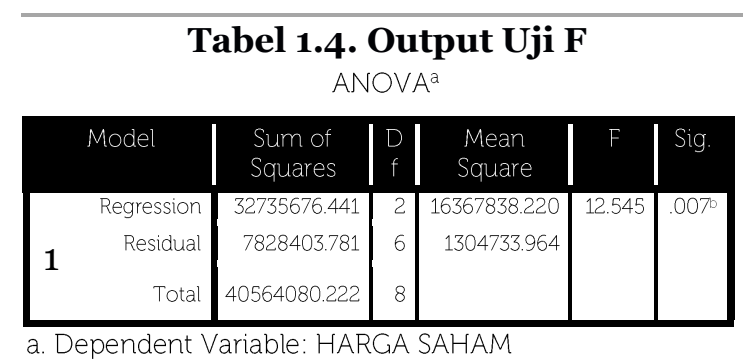


Dari hasil uji $\mathrm{F}$ di atas, diperoleh nilai $F_{\text {hitung }}(12,545)$ lebih besar dari $F_{\text {tabel }}(4,35)$ dengan nilai signifikansi $0,007<0,05$, sehingga disimpulkan $\mathrm{Ho}_{5}$ ditolak $\mathrm{Ha}_{5}$ diterima artinya ROE dan EPS berpengaruh signifikan secara simultan terhadap harga saham.

\section{Uji Koefisien Determinasi}

Tabel 1.5. Uji KoefisDeterminasi

Model Summary b

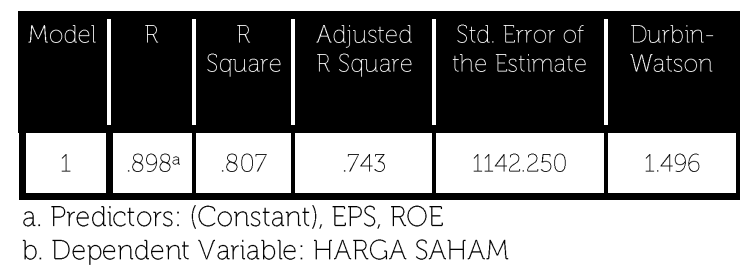

Berdasarkan hasil uji koefisien determinasi diperoleh besarnya nilai pengaruh variabel bebas ditunjukkan oleh nilai $\mathrm{R}$ Square $=$ 0,807 - ini berarti bahwa konstribusi ROE dan EPS terhadap harga saham sebesar 80,7\% sedangkan 19,3\% dipengaruhi oleh variabel lain yang tidak diteliti.

\section{Uji Regresi Linier Berganda}

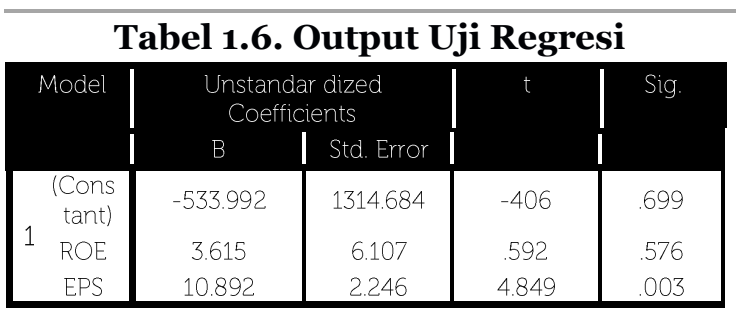

Dengan demikian maka dapat dibentuk persamaan regresi linier berganda $\mathrm{Y}=$ $533,992+3,616\left(\mathrm{X}_{1}\right)+10,892\left(\mathrm{X}_{2}\right)$, yang berarti:

a. Nilai konstanta adalah negatif 533,992 ini dapat diartikan jika ROE dan EPS bernilai o maka nilai harga saham adalah negatif 533,992.

b. Nilai koefisien regresi ROE bernilai positif 3.615 dapat diartikan bahwa setiap peningkatan ROE satu satuan maka akan menaikkan harga saham sebesar 3.615 satuan dengan asumsi variabel lainnya tidak dilakukan atau sama dengan 0.

c. Nilai koefisien regresi EPS bernilai positif 10,892 dapat diartikan bahwa setiap peningkatan EPS satu satuan maka akan menaikkan harga saham sebesar 10,892 satuan dengan asumsi variabel lainnya tidak dilakukan atau sama dengan 0.

\section{Pembahasan}

1. Hasil uji t variable $\mathrm{X} 1$ Return On Equity terhadap variable $\mathrm{Y}$ Harga Saham menunjukkan nilai t hitung 0,592 lebih kecil dari t tabel 2,36462 dan dengan nilai signifikansi sebesar o,576 lebih besar dari 0,05. Dengan demikian dapat disimpulkan bahwa secara parsial Return On Equity (ROE) tidak berpengaruh signifikan terhadap Harga Saham.

2. Hasil uji $t$ variable $\mathrm{X} 2$ Earning Per Share terhadap variable Y Harga Saham menunjukkan nilai $\mathrm{t}$ hitung 4,849 lebih besar dari t tabel 2,365 dan dengan nilai signifikansi sebesar 0.003 di bawah 0,05. Dengan demikian dapat disimpulkan bahwa secara parsial Earning Per Share (EPS) berpengaruh signifikan terhadap Harga Saham.

3. Hasil uji F pengaruh variable X1 Return On Equity, X2 Earning Per Share secara bersama-sama terhadap 
variabel terikat $\mathrm{Y}$ Harga Saham menunjukkan nilai $\mathrm{F}$ hitung 12,545 lebih besar dari $\mathrm{F}$ tabel 4,35 dengan nilai signifikansi $0.007<0,05$. Dengan demikian dapat disimpulkan bahwa secara bersama-sama Return On Equity, Earning Per Share berpengaruh terhadap variabel terikat Harga Saham.

\section{SIMPULAN}

\section{Kesimpulan}

Berdasarkan hasil analisis pada bab sebelumnya, maka dapat disajikan kesimpulan sebagai berikut:

1. Secara parsial Return On Equity (ROE) tidak berpengaruh signifikan terhadap Harga Saham dengan hasil uji $t$ diperoleh nilai $t_{\text {hitung }} 0,592$ lebih kecil dari $t_{\text {tabel }} 2,365$ dan nilai signifikansi sebesar 0,576 lebih besar dari 0,05.

2. Secara parsial Earning Per Share (EPS) berpengaruh signifikan terhadap Harga Saham dengan hasil uji $t$ diperoleh nilai $t_{\text {hitung }}$ 4,849 lebih besar dari $t_{\text {tabel }}$ 2,365 dan nilai signifikansi sebesar 0.003 kurang dari 0,05.

3. Secara bersama-sama Return On Equity dan Earning Per Share berpengaruh terhadap Harga Saham dengan hasil uji $\mathrm{F}$ diperoleh nilai $\mathrm{F}$ hitung 12,545 lebih besar dari $\mathrm{F}$ tabel 4,35 dan nilai signifikansi $0.007<$ 0,05 .

\section{Saran}

Beberapa saran yang dapat disampaikan:
1. Bagi peneliti selanjutnya apabila akan melakukan penelitian sejenis yang lebih lanjut sebaiknya peneliti menambah variabel independen lainnya dan menambah periode pengamatan yang lebih lama, sehingga dapat memberikan pengaruh yang lebih besar dan memberikan hasil yang lebih akurat lagi.

2. Bagi investor atau calon investor yang akan menanamkan modalnya, sebaiknya jangan hanya mengacu pada rasio keuangan ini saja karena masih banyak faktor lain yang tidak disebutkan dalam peneltian ini yang dapat menunjukkan nilai perusahaan berdasarkan harga sahamnya.

3. Bagi perusahaan Perbangkan khususnya PT Bank Negara Indonesia Tbk untuk dapat meningkatkan lagi kinerja perusahaan dan mempertahankan nilai laba per lembar saham agar perkembangan harga sahamnya lebih baik atau lebih meningkat lagi sehingga dapat meningkatkan daya tarik investor untuk berinvestasi saham diperusahaan ini.

\section{DAFTAR PUSTAKA}

Amanda, Astrid dkk. 2012. Pengaruh Debt To Equity Ratio, Return On Equity, Earning Per Share, dan Price Earning Ratio Terhadap Harga Saham (Studi pada Perusahaan Food and Beverages yang Terdaftar di BEI Tahun 20o8-2011. Jurnal. 
Darmadji, T dan Fakhrudin M.H. 2006. Pasar Modal di Indonesia Pendekatan Tanya Jawab. Jakarta: Salemba Empat.

Dita, Ines Farah. 2013. Pengaruh Kinerja Keuangan Terhadap Harga Saham”. Penelitian ini dilakukan pada perusahaan otomotif yang terdaftar di Bursa Efek Indonesia periode 2009-2011. Skripsi. Malang: Fakultas Ekonomi. Universitas Brawijaya.

Dwipratama, Gede Priana. 2009. Analisi Pengaruh PBV,DER,EPS,DPR,dan ROA Terhadap Harga Saham Perusahaan Food and beverage yang Terdaftar di Bursa Efek Indonesia Priode 2005-2007 .Jurnal Fahmi, Irham. 2012. Analisis Kinerja Keuangan. Bandung: Alfabeta

Hanafi, Mahmud M. dan Halim, Abdul. 2009. Analisis Laporan Keuangan. Edisi Keempat. Yogyakarta: YKPN.

Handoko, T. Hani. 2011. Manajemen Personalia dan Sumberdaya Manusia. Yogyakarta: Penerbit BPFE.

Harahap, Sofyan Syafri. 2009. Teori Kritis Laporan Keuangan. Jakarta: Bumi Aksara.

Hasibuan, Malayu S.P. 2016. Manajemen Sumber Daya Manusia. Edisi Revisi. Jakarta: Penerbit PT Bumi Aksara.

Itabillah , E Amalia.2013.Pengaruh CR, QR, NPM, ROA, EPS, ROE, DER dan $P B V$ terhadap harga saham perusahaan Property dan Real
Estate yang terdaftar di Bursa Efek Indonesia. Universitas Maritim Raja Ali Haji.

Kasmir. 2010. Analisis Laporan Keuangan. Jakarta: PT Raja Grafindo Persada.

Kasmir. 2012, Analisis Laporan Keuangan. Jakarta : PT. Raja Grafindo Persada.

Kasmir. 2013. Analisis Laporan Keuangan. Rajawali Pers : Jakarta.

Keown, John D. Martin, J. William Petty, David F. Scott, JR. 2011. Manajemen Keuangan: Prinsip \& Penerapan. PT. Indeks, Jakarta.

Munawir, S. 2010. Analisis laporan Keuangan Edisi keempat. Cetakan Kelima Belas. Yogyakarta: Liberty.

Murtiningsih dan Suyanti. 2011. Membuat Tepung Umbi dan Variasi Olahannya. Jakarta: Agro Media Pustaka.

Novitasari, Ema 2013. Pengaruh EPS, PER, DER, ROA, Terhadap Harga Saham Pada Perusahaan Sektor Pertambangan Yang Terdaftar Di Bursa Efek Indonesia Tahun 20102012. Jurnal Sosial dan Politik Vol 3 , No. 12014.

Nurfadilah. 2011. Analisis pengaruh Earning Per share, debt to equity ratio dan return on equity terhadap harga saham PT Unilever Indonesia Tbk. Jurnal. STIE Muhamadyah Samarinda.

Paramasivan dan Subramanian, 2009. Financial Management. New Delhi 
New Age International (P) Ltd., Publishers

Priyatno. 2008. Mandiri Belajar SPSS Bagi Mahasiswa dan Umum. Yogyakarta: MediaKom.

Putu, Laksmi 2014 .Pengaruh Return On Investasi ,Return On Equity ,Earning Per Share, Price Earning Ratio ,Debt To Equity Ratio Terhadap Harga Saham Perusahaan Agriculture di BEI Periode 20092012 .Jurnal

Riyanto. 2012. Dasar-dasar Pembelanjaan, Edisi 4. Yogyakarta: BPFE.

Sari, Puspita. 2014. Pengaruh Current Ratio, Net Profit Margin, Return On Asset, Debt to Equity Ratio, Total Asset Turnover dan Earning Per Share terhadap Harga Saham Perusahaan Industri Barang Konsumsi yang Go Public di Bursa Efek Indonesia Periode Tahun 2010-2013. Universitas Maritim Raja Ali Haji.

Sarwono, Jonathan. (2012). Metode Riset Skripsi Pendekatan Kuantitatif Menggunakan Prosedur SPSS (Edisi Pertama). Jakarta: PT Elex Media Komputindo.

Solihin, Ismail. 2009. Corporate Social Responsibility from Charity to Sustainability. Jakarta : Salemba Empat.

Sugiyono. 2006. Metode Penelitian Kuantitatif Kualitatif dan $R \& D$. Bandung: Alfabeta.
Sugiyono. 2014. Metode Penelitian Pendidikan Pendekatan Kuantitatif, Kualitatif Dan R\&D. Bandung: Alfabeta.

Sugiyono. 2015. Metode Penelitian Pendidikan (Pendekatan Kuantitatif, Kualitatif dan R\&D). Penerbit CV. Alfabeta: Bandung.

Tandelilin, Eduardus. 2010. Portofolio dan Investasi Teori dan Aplikasi. Edisi pertama. Yogyakarta : Kanisius.

Terry, G R. 2010. Manajemen Sumber Daya Manusia. Edisi Pertama. Cetakan Pertama. Jakarta : Penerbit Kencana.

Wijayanto, Dian. 2012. Pengantar Manajemen. Jakarta: PT Gramedia Pustaka Utama. 